\title{
Residual effect of organic carbon as a tool for mitigating nitrogen oxides emissions in semi-arid climate
}

\author{
Laura Sanchez-Martin • Jan Dick • Kaya Bocary • \\ Antonio Vallejo • Ute M Skiba
}

\begin{abstract}
Residual effects of different fertilizers (mineral and organic) on the first pulses of carbon dioxide $\left(\mathrm{CO}_{2}\right)$, nitric oxide (NO), and nitrous oxide $\left(\mathrm{N}_{2} \mathrm{O}\right)$ after rewetting dry soil with or without application of a mineral $\mathrm{N}$ fertilizer were studied in a laboratory experiment. Six months before this study was conducted the fields had received either manure + urea, manure, urea or no fertilizer. In the first phase the soil was rewetted with water simulating a summer shower (heavy rainfall in short time) and in the second phase with a urea solution simulating a mineral fertilization. There were not significant differ-
\end{abstract}

Responsible Editor: Per Ambus.

L. Sanchez-Martin 'A. Vallejo

Escuela Técnica Superior de Ingenieros Agrónomos,

Universidad Politécnica de Madrid,

Ciudad Universitaria,

28040 Madrid, Spain

J. Dick - U. M Skiba

Center for Ecology and Hydrology, Edinburgh, Bush Estate,

Penicuik,

Midlothian EH26 0QB, UK

\section{K. Bocary}

The World Agroforestry Centre, ICRAF Sahel Program, P.O. Box 320, Bamako, Mali

\section{Sanchez-Martin}

Dpto. Química y Análisis Agricola-E.T.S.I. Agrónomos de Madrid, Ciudad Universitaria $\mathbf{s} / \mathbf{n}$,

28040 Madrid, Spain

e-mail: laura.sanchez@upm.es ences in trace gas emissions between earlier field treatments after soil was rewetted with water addition. However, after urea addition, plots that had received manure 6 months earlier showed smaller total emissions of $\mathrm{N}_{2} \mathrm{O}$ and $\mathrm{NO}$ compared to plots that had only received urea. The residual effect of manure can play an important role in carbon poor soils under arid-semiarid climate in mitigating atmospheric pollutants such us $\mathrm{NO}$ and $\mathrm{N}_{2} \mathrm{O}$.

Keywords C residual effect $\cdot$ Nitrogen oxides . WFPS $\cdot$ Arid-semiarid soils $\cdot$ Pulsing effect

\section{Introduction}

Arid and semiarid climates are characterized by wet and dry seasons where soils are dry a large part of the year. During dry seasons, microbiological activity stops and many bacteria, fungi and plants die and increase the nitrogen $(\mathrm{N})$ and carbon $(\mathrm{C})$ in the soil. The first rainfall on dry soil reactivates the remaining microbial community (Cabrera 1993; Davidson 1993), which uses this $\mathrm{N}$ and $\mathrm{C}$ as carbon and energy source and as by-products of their activities emit large pulses of carbon dioxide $\left(\mathrm{CO}_{2}\right)$, nitric oxide $(\mathrm{NO})$ and nitrous oxide $\left(\mathrm{N}_{2} \mathrm{O}\right)$ to the atmosphere (Muller et al. 2002, Werner et al. 2007). This effect is known as the pulsing effect. Such pulses of trace gas emission can make a significant contribution to the total annual $\mathrm{N}_{2} \mathrm{O}$ and NO budget, as shown by Scholes et al. 
(1997) for African savanna soils and by Conrad (2002) for a German forest soil.

Even in temperate climates wetting and drying cycles can trigger the pulsing effect (Christensen and Tiedje 1990; Jorgensen et al. 1998), but independent of the start of the rainy period, localized heavy showers in summer can activate the pulsing effect. In these situations high temperatures increase evapotranspiration rates and consequently reduce the soil moisture content of the top soil very rapidly. These changes will directly affect the soil microbial biomass, including nitrifiers and denitrifiers. Such situations are very common in arid-semiarid climates, however not many studies have evaluated their effect on $\mathrm{N}_{2} \mathrm{O}$ and $\mathrm{NO}$ emissions (Cabrera 1993; Cardenas et al. 1993).

Soils in arid-semiarid areas typically have low organic carbon contents. Incorporation of organic matter or mineral $\mathrm{N}$ fertilizers produce higher fertility in these soils but at the same time can increase microbial emissions of $\mathrm{N}_{2} \mathrm{O}, \mathrm{NO}$ and $\mathrm{CO}_{2}$ (Peoples et al. 1995; Dick et al. 2001). Some studies support the idea that in soils with low organic $\mathrm{C}$ under semi-arid conditions organic fertilizer can mitigate $\mathrm{N}_{2} \mathrm{O}$ emissions compared to mineral fertilizers under conditions favouring denitrification (Vallejo et al. 2006; Meijide et al. 2007). These authors suggested that the incorporation of labile $\mathrm{C}$ compounds reduced $\mathrm{N}_{2} \mathrm{O}$ / $\mathrm{N}_{2}$ ratio and consequently $\mathrm{N}_{2} \mathrm{O}$ emissions. Although soil labile $\mathrm{C}$ disappears rapidly after fertilizer application, Chantigny et al. (2002) reported that mineralization in organic amended soils continues for a long period of time (residual effect), replacing labile organic $\mathrm{N}$ and $\mathrm{C}$ compounds. The questions that we wish to address in this work are (1) whether the residual effect of organic fertilizers could have an influence on $\mathrm{N}_{2} \mathrm{O}$ and $\mathrm{NO}$ emissions when the soil is rewetted with the first rainfall, even $6-8$ months after fertilizer application; and (2) how does the residual effect of organic fertilizers applied during the previous season influence $\mathrm{NO}, \mathrm{N}_{2} \mathrm{O}$ and $\mathrm{CO}_{2}$ emissions after new fertilization with mineral $\mathrm{N}$.

\section{Material and methods}

Soil and treatments

Soil was sampled from 3 arable fields located in an arid region. Ségou, $250 \mathrm{~km}$ northeast of Bamako,
Mali, Africa. The fields were managed in a legume/ cereal crop rotation. At time of sampling the crop was cereal. The soil was an alfisol with a sandy texture and a bulk density of $1.57 \mathrm{~g} \mathrm{~cm}^{-3}$. The soil $\mathrm{pH}$ was 7.5 and the organic matter content $0.32 \%$.

The fields were fertilized six months before sample collection (July 2003). The different treatments were: manure with and without urea $(+\mathrm{M}+\mathrm{N}$ and $+\mathrm{M}-\mathrm{N}$, respectively), urea without manure $(-\mathrm{M}+\mathrm{N})$ and a control without manure or urea $(-\mathrm{M}-\mathrm{N})$. Manure was a mixture of cow dung and goat / sheep droppings and was added at a rate of $8000 \mathrm{~kg} \mathrm{ha}^{-1}$ (dry weight) and urea was added at the same time as manure at a rate of $50 \mathrm{~kg} \mathrm{~N} \mathrm{ha}^{-1}$. In January 2004 , during the dry season, five soil sub-samples ( $\sim 100 \mathrm{~g}$ each) were randomly collected of the top $0-20 \mathrm{~cm}$ of field soil within each plot $(10 \mathrm{~m} \times 10 \mathrm{~m})$ which received the fertilizers described above. These five soil sub-samples from the same plot were bulked, passed through a $2 \mathrm{~mm}$ sieve, air dried and transported by air to Centre of Ecology and Hydrology (CEH) of Edinburgh to carry out a laboratory experiment. A total of 12 bulked soil samples, which include 4 treatments $(+\mathrm{M}+\mathrm{N} ;+\mathrm{M}-\mathrm{N}$; $-\mathrm{M}+\mathrm{N} ;-\mathrm{M}-\mathrm{N}$ ) in 3 replicates were available for this study.

\section{Experiment setup}

An aliquot of $150 \mathrm{~g}$ soil of each sample collected was placed into a clear Perspex column $(20 \mathrm{~cm}$ height $\times 5 \mathrm{~cm}$ diameter), which was sealed at the base and during flux measurements also at the top with a plastic lid and insulating tape. The soil column was about $4.4 \mathrm{~cm}$ high, leaving a headspace of 0.3321 with a bulk density very similar that in the field $\left(1.6 \mathrm{~g} \mathrm{~cm}^{-3}\right)$. Gas inlet and outlet holes $(0.5 \mathrm{~cm})$ were fitted with three way taps; the outlet hole was placed $50 \mathrm{~mm}$ above the inlet (Dick et al. 2001).

In order to not disturb the soil during gas sample time, additional aliquots of $100 \mathrm{~g}$ of soil were placed in similar diameter containers, which were periodically sub-sampled for gravimetric soil moisture content and soil mineral $\mathrm{N}$ content analysis. All soils (100 $\mathrm{g}$ and $150 \mathrm{~g}$ aliquots) were incubated under the same conditions, especially for soil moisture content which was exactly the same in all columns. Air temperature in the laboratory was constant $\left(25.5^{\circ} \mathrm{C} \pm\right.$ $0.9^{\circ} \mathrm{C}$ ), simulating typical atmospheric conditions observed at the experimental field site in Mali. 
In the first phase a pulsing effect was induced by adding a total of $30 \mathrm{ml}$ of water, (equivalent to $15 \mathrm{~mm}$ rainfall), to the soil columns which increased the soil water status above field capacity (WFPS $>80 \%$ ). Fluxes of $\mathrm{NO}, \mathrm{CO}_{2}$ and $\mathrm{N}_{2} \mathrm{O}$ were measured one day before simulating the rainfall event and then once daily for the following 9 days until the soil returned to dry conditions.

In the second phase, a mineral fertilization was simulated adding urea solution to the soils, in order to study the residual effect of soil organic $\mathrm{C}$ on the pulsing effect after new fertilization. This phase started when the soil returned to dry conditions after the first phase, which was defined as constant weight and corresponded to WFPS of $20 \%$. This time $30 \mathrm{ml}$ of a urea solution, equivalent to an addition of $50 \mathrm{~kg}$ urea- $\mathrm{N} \mathrm{ha}^{-1}$, was added to soil cores. Trace gas fluxes were measured daily for the first 5 days after treatment and then less frequently for the following 15-18 days.

Measurements were made just after the water or urea application when the soil moisture was high (WFPS $>80 \%$ ) until the soil dried out to a constant weight equivalent to a WFPS of $20 \%$. A constant WFPS was deliberately not maintained, in order to simulate fast and heavy rainfall events typical for semi-arid climates.

Trace gas flux measurements

Nitric oxide (NO) fluxes were analysed by chemiluminescense (42C NOx analyser, Thermo Environmental Instruments Inc Franklin, MA, USA) using a gas flow-through system, as described in detail by Sanchez-Martin et al. (2008). Flux measurements from soil columns were recorded at $10 \mathrm{sec}$ intervals on a datalogger (Campbell Scientific 21x) until the system reached steady state conditions, approximately $20 \mathrm{~min}$. Three measurements on an empty column were also taken in order to take into account reactions with the chamber walls and lid. The NO flux was calculated as the product of the flow rate of the air stream through the repacked soil column, the increase in NO concentration above the empty column (control) in the steady state and the dilution rate divided by the area of soil surface $(0.002)$ and dry weight of soil $(150 \mathrm{~g})$.

After the NO measurements, $\mathrm{N}_{2} \mathrm{O}$ and $\mathrm{CO}_{2}$ fluxes were measured from samples extracted from the headspace of the soil columns after sealing for about
$30 \mathrm{~min}$. Gas samples $(20 \mathrm{ml})$ were withdrawn by syringe and analyzed within $5 \mathrm{~h}$. All gases were analyzed by gas chromatography (Hewlett Packard 5890 ), using an electron-capture detector for $\mathrm{N}_{2} \mathrm{O}$ and a flame ionization detector fitted with a methanizer for $\mathrm{CO}_{2}$. Ambient room air was collected at the beginning of each sample set. Gas emissions in the columns increased linearly during the enclosure period, which was confirmed with a test realized before the experiment. The $\mathrm{N}_{2} \mathrm{O}$ and $\mathrm{CO}_{2}$ fluxes were calculated assuming a linear increase in headspace concentration and using ambient air as start concentration

\section{Soil analysis}

The columns created for destructive sampling were analysed on day 1 and 10 after either water or urea addition for soil available $\mathrm{NH}_{4}{ }^{+}$and $\mathrm{NO}_{3}{ }^{-}$concentrations and gravimetric soil moisture content daily by weight loss. As it was not possible to analyse mineral $\mathrm{N}$ concentrations by the conventional colorimetric method after extraction with $\mathrm{KCl}$ (Harwood and Huysen 1970; Henriksen and Selmer-Olsen Henriksen \& Selmer-Olsen 1970), mineral $N$ concentrations were estimated using Spectroquant $\mathrm{NH}_{4}{ }^{+}$and $\mathrm{NO}_{3}{ }^{-}$test strips, which have a detection limit of 2.6 to $193 \mathrm{ppm}$ for $\mathrm{NH}_{4}{ }^{+}$and from 0.45 to $111 \mathrm{ppm}$ for $\mathrm{NO}_{3}{ }^{-}$(Merck). Loss on ignition was used to estimate soil carbon content (Rowell 1994). Gravimetric moisture contents for the columns were derived from the relationship between wet weight of the soil column and destructive sample and the gravimetric soil moisture content of the latter. The water filled pore space (WFPS) was calculated by dividing the volumetric water content (product of gravimetric soil moisture content and bulk density) by total soil porosity. Total soil porosity was calculated according to the relationship: soil porosity $=$ (1- soil bulk density / 2.65), assuming a particle density of $2.65 \mathrm{~g} \mathrm{~cm}^{-3}$. Bulk densities were calculated from the volume of soil in the cores.

\section{Statistical analysis}

The statistical analysis was performed using STATGRAPHICS Plus 5.1 (Manugistics Manugistics 2000). The least significant difference (LSD) test was used for comparison of means between treatments. Simple ANOVA analysis determined whether $\mathrm{N}_{2} \mathrm{O}, \mathrm{NO}$ and $\mathrm{CO}_{2}$ emissions were related to the treatments. 


\section{Results}

Phase 1: Addition of water to dry soils

The addition of water stimulated a small $\mathrm{N}_{2} \mathrm{O}$ pulse from all treatments on the third day after water addition (Fig. 1). Thereafter the WFPS decreased rapidly from $59 \%$ to $5 \%$ and $\mathrm{N}_{2} \mathrm{O}$ cmissions mirrored this decrease and declined to a flux smaller than $0.1 \mathrm{ng} \mathrm{N} \mathrm{N}_{2} \mathrm{O}-\mathrm{N} \mathrm{g}^{-1} \mathrm{~h}^{-1}$ (days 4 to 12), except for a small second $\mathrm{N}_{2} \mathrm{O}$ pulse on day 9 although smaller than the first one. In general $\mathrm{CO}_{2}$ emissions behaved similar to $\mathrm{N}_{2} \mathrm{O}$ emissions (Fig. 1) but there was no sccond $\mathrm{CO}_{2}$ peak. Pulses of NO emissions following the simulated rainfall event occurred later than the first $\mathrm{N}_{2} \mathrm{O}$ and $\mathrm{CO}_{2}$ peaks but coincided with the sceond peak of $\mathrm{N}_{2} \mathrm{O}$ (Fig. 1). Largest cmissions of NO occurred from day 6 to 10 after water application, when the WFPS ranged from 24 to $12 \%$.
Fig. 1 Emission of $\mathrm{N}_{2} \mathrm{O}$ (a); $\mathrm{NO}$ (b); $\mathrm{CO}_{2}$ (c) during water and urea additions and changes in WFPS throughout the experimental period (d). The verticals bars indicate LDS at 0.05 between treatments. Symbols represent soils samples from the following treatments: $\bullet,+\mathrm{M}+\mathrm{N} ; \mathrm{\square},+\mathrm{M}-\mathrm{N}$; $\boldsymbol{A},-\mathrm{M}+\mathrm{N} ; \mathbf{a},-\mathrm{M}-\mathrm{N}$

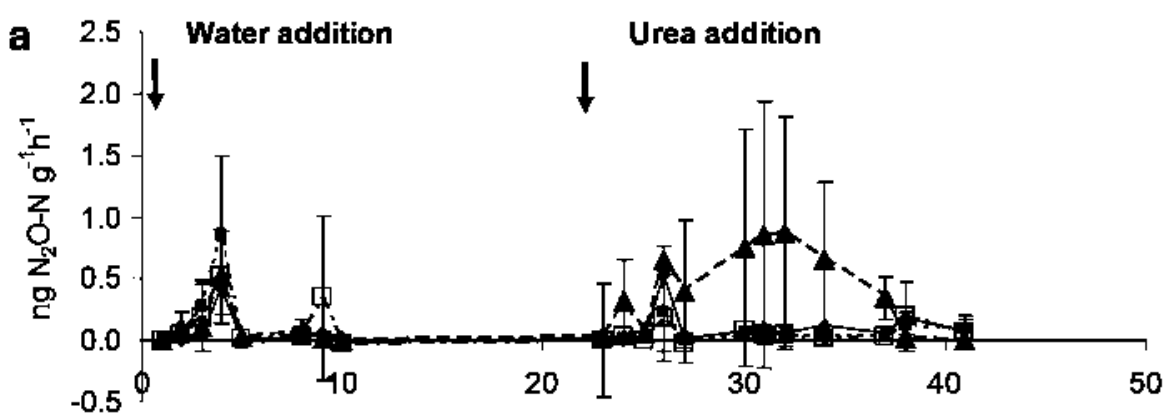

b
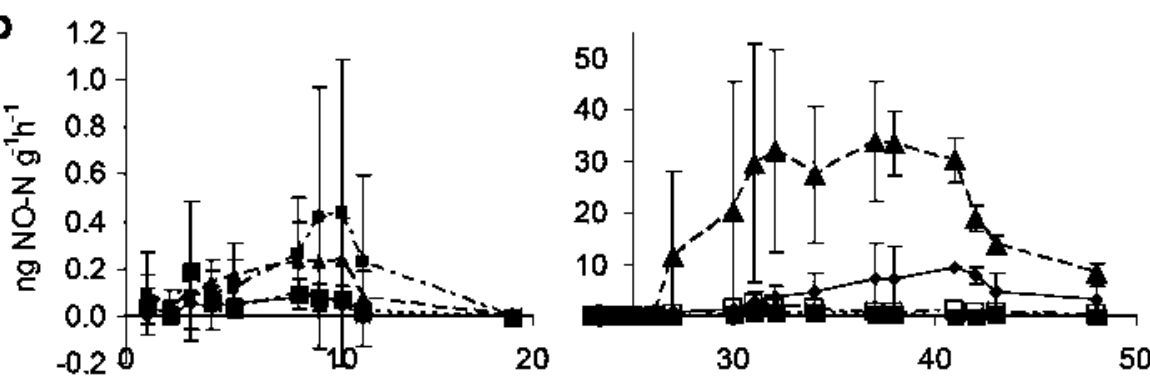

C

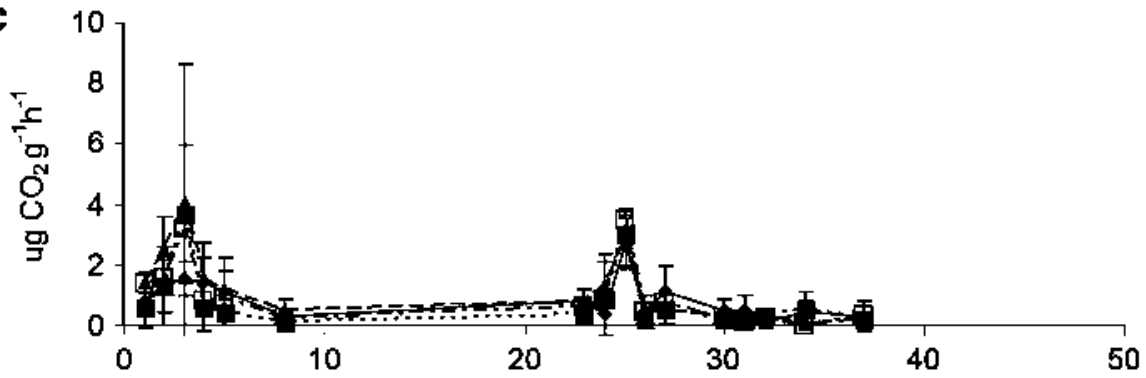

d

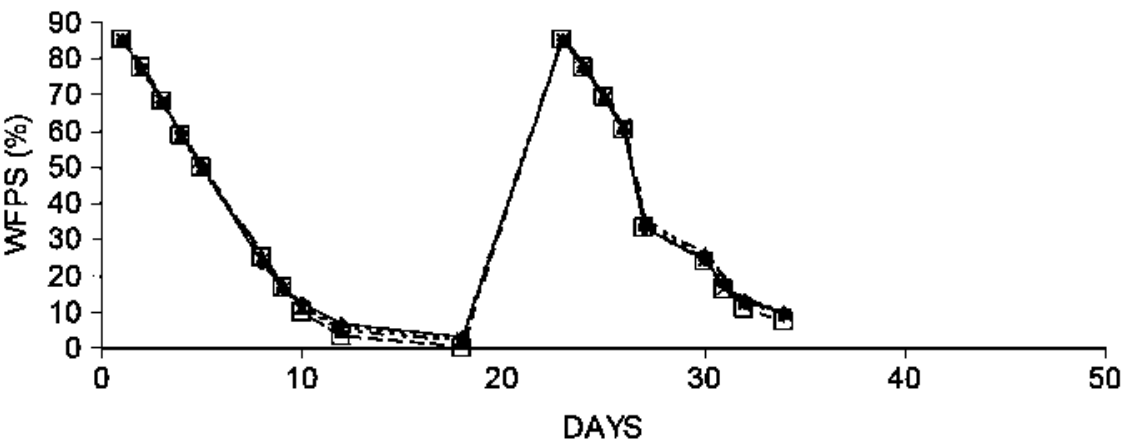


In general, there were no significant differences in the total $\mathrm{N}_{2} \mathrm{O}, \mathrm{CO}_{2}$ or $\mathrm{NO}$ emissions between treatments following the simulated rainfall event (Table 1).

Phase 2: Addition of urea to dry soils

Urea was added 23 days after water application when the soil had dried out to a WFPS $<20 \%$ and returned the WFPS from $20 \%$ to $80 \%$, triggering pulses of $\mathrm{N}_{2} \mathrm{O}$, NO and $\mathrm{CO}_{2}$ (Fig. 1). The highest $\mathrm{N}_{2} \mathrm{O}$ flux from this pulse was $0.86 \mathrm{ng} \mathrm{N} \mathrm{N}_{2} \mathrm{O}-\mathrm{N} \mathrm{g}^{-1} \mathbf{h}^{-1}$ from the $-\mathrm{M}+\mathrm{N}$ treatment, which lasted for 18 days and stopped emitting when the WFPS was reduced to $12 \%$ (Fig. 1). For the remaining treatments a pulse of $\mathrm{N}_{2} \mathrm{O}$ was only observed on day 27 (Fig. 1), four days after urea application, when the WFPS was close to $60 \%$. The cumulative $\mathrm{N}_{2} \mathrm{O}$ emission for the period 23 to 40 days ranged from -0.1 to $5.6 \mathrm{ng} \mathrm{N}_{2} \mathrm{O}-\mathrm{N} \mathrm{g}^{-1}$ (Table 1), and was significantly larger for the $-\mathrm{M}+\mathrm{N}$ treatment $(\mathrm{P}<0.05)$.

The $\mathrm{CO}_{2}$ peak after urea addition was similar to the $\mathrm{CO}_{2}$ pulse produced following water addition. The $\mathrm{CO}_{2}$ peak occurred, three days after urea application on day 26 (Fig. 1), and all treatments had very similar emission rates $\left(2.5-3.5 \mu \mathrm{g} \mathrm{CO}_{2} \mathrm{~g}^{-1} \mathrm{~h}^{-1}\right)$. For both experiments (water or urea additions) $\mathrm{CO}_{2}$ peak occurred when the WFPS was around $68 \%$. Cumulative $\mathrm{CO}_{2}$ emissions were the same for all treatments $\left(6.44-7.32 \mu \mathrm{g} \mathrm{CO}_{2} \mathrm{~g}^{-1}\right.$ ) (Table 1).

Rewetting the soil with urea solution resulted in a significantly larger pulse of $\mathrm{NO}(p<0.05)$ compared to the water treatment alone (Fig. 1). Largest $\mathrm{NO}$ emissions ( $33.8 \mathrm{ng} \mathrm{NO}-\mathrm{N} \mathrm{g}^{-1} \mathbf{h}^{-1}$ ) were recorded from soil cores collected from the plots previously treated with only inorganic fertilizer in the field $(-\mathrm{M}+\mathrm{N})$. Similarly the total $\mathrm{NO}$ emitted (260.35 $\mathrm{ng} \mathrm{NO}-\mathrm{Ng}^{-1}$ ) from this treatment was significantly larger $(p<0.01)$ than from the other treatments $\left(3.8-43.9 \mathrm{ng} \mathrm{NO}-\mathrm{Ng}^{-1}\right)$ (Table 1).

Mineral $\mathrm{N}$ and $\mathrm{C}$ changes after water and urea additions

Following water addition (WFPS $80 \%$ ), $\mathrm{NO}_{3}^{-}$and $\mathrm{NH}_{4}{ }^{+}$concentrations increased slightly for all treatments (Table 2). Soil collected from plots previously treated with only inorganic fertiliser $(-\mathrm{M}+\mathrm{N})$ had the largest mineral $\mathrm{N}$ concentrations (5.00 and $6.27 \mu \mathrm{g} \mathrm{N}$ $\mathrm{g}^{-1}$ dry soil of $\mathrm{NO}_{3}{ }^{-}$and $\mathrm{NH}_{4}{ }^{+}$respectively) compared to soil that had not received mineral $\mathrm{N} 6$ month earlier (+M-N or $-\mathrm{M}-\mathrm{N})$. Mineral $\mathrm{NO}_{3}^{-}$and $\mathrm{NH}_{4}{ }^{+}$concentrations after urea application (Table 2) ranged from 3.29 to 5.33 and from 73.25 to $100.31 \mu \mathrm{g} \mathrm{N} \mathrm{g}$ dry soil for $\mathrm{NO}_{3}{ }^{-}$and $\mathrm{NH}_{4}{ }^{+}$, respectively.

$\mathrm{NO}$ emissions correlated with total mineral $\mathrm{N}$ $\left(\mathrm{NH}_{4}{ }^{+}\right.$plus $\left.\mathrm{NO}_{3}{ }^{-}\right)\left(\mathrm{r}^{2}=0.98\right)$ following urea addition. There was no significant relationship between $\mathrm{N}_{2} \mathrm{O}$ or $\mathrm{CO}_{2}$ emissions and available $\mathrm{N}$ in the urea experiment or between $\mathrm{NO}, \mathrm{N}_{2} \mathrm{O}$ or $\mathrm{CO}_{2}$ emission and available $\mathrm{N}$ in the water experiment. Total organic $\mathrm{C}$ contents were not statistically significantly different before and after the start of the experiment $(0.17 \%-0.19 \%)$.

$\mathrm{NO} / \mathrm{N}_{2} \mathrm{O}$ Ratio after water and urea additions

When the WFPS was larger than $60 \%$, the $\mathrm{NO} / \mathrm{N}_{2} \mathrm{O}$ ratio was $<1$ in almost all treatments, both after simulated rainfall and urea additions. Only soil collected from the $+\mathrm{M}-\mathrm{N}$ treatment following urea application showed a ratio $>1$. When the WFPS was less than $60 \%$ all treatments in both experiments exhibited a $\mathrm{NO} / \mathrm{N}_{2} \mathrm{O}$ ratio $>1$.

Table 1 Cumulative $\mathrm{N}_{2} \mathrm{O}, \mathrm{NO}$ and $\mathrm{CO}_{2}$ fluxes emitted after water or urea application to soils treated in the field with or without manure $(\mathrm{M})$ and with or without wea $(\mathrm{N})$ six months before the soils were collected

\begin{tabular}{|c|c|c|c|c|c|c|}
\hline \multirow[t]{2}{*}{ Treatment in the field } & \multicolumn{2}{|c|}{$\mathrm{N}_{2} \mathrm{O}$ ng $\mathrm{N}_{2} \mathrm{O}-\mathrm{Ng}^{-1}$ soil } & \multicolumn{2}{|c|}{ NO ng $\mathrm{NO}-\mathrm{Ng}^{-1}$ soil } & \multicolumn{2}{|c|}{$\mathrm{CO}_{2} \mu \mathrm{g} \mathrm{CO}_{2} \mathrm{~g}^{-1}$ soil } \\
\hline & Water & Urea & Water & Urea & Water & Urea \\
\hline$+\mathrm{M}+\mathrm{N}$ & $0.05 \mathrm{a}$ & $1.20 \mathrm{a}$ & $0.40 \mathrm{a}$ & $43.91 \mathrm{a}$ & $6.50 \mathrm{a}$ & $7.32 \mathrm{a}$ \\
\hline$-\mathrm{M}+\mathrm{N}$ & $0.87 \mathrm{a}$ & $5.60 \mathrm{~b}$ & $1.32 \mathrm{a}$ & $260.35 \mathrm{~b}$ & $11.30 \mathrm{a}$ & $7.29 \mathrm{a}$ \\
\hline$+\mathrm{M}-\mathrm{N}$ & $1.15 \mathrm{a}$ & $-0.1 \mathrm{a}$ & $1.78 \mathrm{a}$ & $11.90 \mathrm{a}$ & $7.90 \mathrm{a}$ & $7.03 \mathrm{a}$ \\
\hline$-\mathrm{M}-\mathrm{N}$ & $1.12 \mathrm{a}$ & $0.40 \mathrm{a}$ & $0.61 \mathrm{a}$ & $3.81 \mathrm{a}$ & $6.85 \mathrm{a}$ & $6.44 a$ \\
\hline
\end{tabular}

Data shown are averages of three replicates. Different letters within each column indicate significant differences between fertilizer treatments using Fisher's Unprotected Least Significant Difference test, $p<0.05$. 
Table 2 Changes in soil available $\mathrm{NO}_{3}{ }^{-}$and $\mathrm{NH}_{4}{ }^{+}$concentrations in the $0-10 \mathrm{~cm}$ soil layer during the three steps of the experiment: before water addition (dry soil); after water addition and after wea addition

\begin{tabular}{|c|c|c|c|c|c|c|}
\hline \multirow[t]{2}{*}{ Treatment } & \multicolumn{3}{|c|}{$\mathrm{NO}_{3}^{-}$( $\mu \mathrm{g} \mathrm{N} \mathrm{g}^{-1}$ dry soil) } & \multicolumn{3}{|c|}{$\mathrm{NH}_{4}^{+}\left(\mu \mathrm{g} \mathrm{N} \mathrm{g}{ }^{-1}\right.$ dry soil $)$} \\
\hline & Dry soil & Water & Urea & Dry soil & Water & Urea \\
\hline$+\mathrm{M}+\mathrm{N}$ & $0.71 \mathrm{a}$ & $2.10 \mathrm{a}$ & $5.33 \mathrm{a}$ & $1.14 \mathrm{ab}$ & $1.92 \mathrm{a}$ & 84.66 a \\
\hline$-\mathrm{M}+\mathrm{N}$ & $3,47 \mathrm{c}$ & $5.00 \mathrm{~b}$ & $3.95 \mathrm{a}$ & $5.62 \mathrm{c}$ & $6.27 \mathrm{~b}$ & $100.31 \mathrm{a}$ \\
\hline$+\mathrm{M}-\mathrm{N}$ & $2.33 \mathrm{~b}$ & $3.26 \mathrm{ab}$ & $4.15 \mathrm{a}$ & $2.42 \mathrm{bc}$ & $3.21 \mathrm{ab}$ & 75.97 a \\
\hline$-\mathrm{M}-\mathrm{N}$ & $1.26 \mathrm{a}$ & $1.62 \mathrm{a}$ & $3.29 \mathrm{a}$ & $1.09 \mathrm{ab}$ & $1.38 \mathrm{a}$ & $73.25 \mathrm{a}$ \\
\hline
\end{tabular}

Symbols $+M$; $-M$ and $+N ;-N$ refer to treatments with and without manure $(M)$ and urea $(N)$ in the field six months before soils were collected. Data shown are averages of three replicates. Different letters within each column indicate significant differences between fertilizer treatments using Fisher's Unprotected Least Significant Difference test, $p<0.05$.

\section{Discussion}

Residual effect after water addition

The application of water to dry soils produced a shortlived pulse of $\mathrm{CO}_{2}, \mathrm{NO}$, and $\mathrm{N}_{2} \mathrm{O}$ emissions. This observation is in agreement with previous studies from tropical soils (Scholes et al. 1997; Brever et al. 2000; Dick et al. 2001). The source of this "pulse" is thought to be the reactivation of nitrifying and denitrifying microorganisms in the soil, utilising the increased amount of easily decomposable organic $\mathrm{C}$ and $\mathrm{N}$ present due to death of other microbes and residual organic material from previous land management practice (Birch 1985; Cabrera 1993). Results of this experiment demonstrated that the pulse of these gases after the first rainfall on this soil was not affected by the residual effect of the fertiliser that had been applied 6 months before, in spite of the fact that $\mathrm{NH}_{4}{ }^{+}$and $\mathrm{NO}_{3}{ }^{-}$contents were higher in the mineral fertiliser treatment $(-M+N)$ for the dry soil than in the others (Table 2). When dry soil is rewetted, respiration rates increase rapidly (Haney et al. 2004). However comparing this experiment with other field or laboratory experiments (Jones et al. 2005, SanchezMartin et al. 2008), respiration rates were very small. The pulse of $\mathrm{CO}_{2}$ was only maintained for two days when the WFPS was higher than $60 \%$. According to Doran et al. (1988) microbial activity is optimal around a WFPS of $55-60 \%$, however in this experiment soil moisture decreased below $60 \%$ WFPS after two days due to the rapid evapotranspiration. Thereafter the low moisture content limited soil respiration and other microbial processes (Orchard and Cook 1983). There are many factors, which control soil respiration, such as temperature, soil type and dissolved organic carbon (DOC) content, but soil moisture is one of the principal factors which influences soil respiration in arid or semiarid ecosystems(Conant et al. 2001).

The transient $\mathrm{CO}_{2}$ peaks observed suggest that when the soil was rewetted the microbial population first consumed the more labile organic $\mathrm{C}$ and $\mathrm{N}$ molecules of the organic soil fraction, which includes microorganisms that died during the dry period. No residual effect of these manure applications was observed, possibly because optimal moisture conditions for respiration were too transient to maximise decomposition of the organic fertiliser incorporated into the fields 6 months earlier.

Maximum $\mathrm{CO}_{2}$ and $\mathrm{N}_{2} \mathrm{O}$ emission, peaked on the third and fourth day after water application (WFPS> $70 \%$ ), respectively, while maximum NO emission was observed on the tenth day (WFPS $<30 \%$ ) (Fig. 1 ). Although denitrification was not measured in this experiment, $\mathrm{NO} / \mathrm{N}_{2} \mathrm{O}$ emission ratios may provide an indication of the dominant process responsible for $\mathrm{NO}$ emission. Nitrification and denitrification often occur simultaneously, but nitrification dominates when the $\mathrm{NO} / \mathrm{N}_{2} \mathrm{O}$ ratio is close to the unity and denitrification dominates when this ratio is less than unity (FAO 2001). In this laboratory experiment, the fast changes in the soil moisture, simulating a single rainfall event in a hot climate, has a large influence on the balance between both processes. After soil was rewetted, WFPS was $>60 \%$ and $\mathrm{NO} / \mathrm{N}_{2} \mathrm{O}$ ratio was $<1$ indicating that denitrification was the main source of $\mathrm{N}_{2} \mathrm{O}$ but only during the first two days because after that, soil moisture returned to below $60 \%$ WFPS coinciding with a $\mathrm{NO} / \mathrm{N}_{2} \mathrm{O}$ ratio $>1$. These results suggest that 
denitrification was the main source of $\mathrm{N}_{2} \mathrm{O}$ emissions while nitrification was the main source of $\mathrm{NO}$. However, nine days after wetting the soil, there was a second $\mathrm{N}_{2} \mathrm{O}$ peak, smaller than the first, which was coincident with the NO peak at WFPS $<60 \%$. This suggests that $\mathrm{N}_{2} \mathrm{O}$ was produced by nitrification at this time, which is in agreement with Sahrawat \& Keeny (1986), who demonstrated that $\mathrm{N}_{2} \mathrm{O}$ pulses produced by nitrification processes are normally small.

This first phase of the experiment clearly showed that pulses of soil trace gas emissions stimulated by a typical single summer shower (a heavy burst of rain) are short lived, not very strong and are not influenced by the residual effect of previously applied fertilizer due to extreme temperatures and high evapotranspiration.

\section{Residual effect after urea addition}

The application of urea solution resulted in $\mathrm{N}_{2} \mathrm{O}$ peaks similar to that of rain alone (Fig. 1). The rate and duration of the emission peaks were the same in all treatments except the $-\mathrm{M}+\mathrm{N}$ treatment. Soil from this treatment initially emitted $\mathrm{N}_{2} \mathrm{O}$ when the WFPS was higher than $65 \%$ but contrary to the other treatments, the emission rate was still increasing until the WFPS declined to $12 \%$. In this second phase of the experiment, $\mathrm{N}_{2} \mathrm{O}$ and $\mathrm{NO}$ emissions were reduced by $78 \%$ and $83 \%$ respectively from the $+\mathrm{M}+\mathrm{N}$ compared to the $-\mathrm{M}+\mathrm{N}$ treatment. These results are very important because even six months after manure application its reducing effect on nitrogen oxides emissions was maintained. Before soils were collected for this experiment, Dick et al. (2008) measured $\mathrm{N}_{2} \mathrm{O}$ emissions from all the treatment plots in the field using static chambers. As in the laboratory study, $\mathrm{N}_{2} \mathrm{O}$ emissions were significantly larger for the $-\mathrm{M}+\mathrm{N}$ treatment than $+\mathrm{M}-\mathrm{N}$ or $+\mathrm{M}+\mathrm{N}$ treatments.

Although $\mathrm{N}_{2} \mathrm{O}$ started to be emitted at high moisture conditions, $78 \%$ of all emissions occurred under conditions were nitrification is thought to be the dominant process (WFPS $<40 \%$ ) (Fig. 1). The main question is why soil treated 6 months previously with manure reduced $\mathrm{NO}$ and $\mathrm{N}_{2} \mathrm{O}$ emissions more than 4 fold, and especially under nitrification favouring conditions? No simple explanation was found. Organic amendments to $\mathrm{C}$ poor soil should lead to an increased total C content (Bastida et al. 2009). However, in this experiment the differences in organic matter content between the treatments were not significant. There may have been differences in the quality of the organic material available and $D O C$ content may have been larger in the manure treated soils. But DOC was not measured in this experiment. The presence of labile organic carbon could in theory stimulate the immobilisation of mineral $\mathrm{N}$ and thereby reduce $\mathrm{NO}$ and $\mathrm{N}_{2} \mathrm{O}$ emissions, however in this laboratory study the mineral $\mathrm{N}$ concentrations were not significantly different for the manure and no manure treatments. The application of organic fertilizers could have stimulated microbial activity (Deng and Tabatabai 1997), increasing the consumption of $\mathrm{O}_{2}$ and thereby creating microsites with the necessary reduced redox potential required for $\mathrm{NO}$ and $\mathrm{N}_{2} \mathrm{O}$ production (Beauchamp et al. Beauchamp et al. 1989). However there is no evidence that this was the case in our study, as $\mathrm{CO}_{2}$ emissions were not significantly different between the manure and no manure treatments.

The addition of simple (glucose) and complex (red clover and barley residue) carbon sources was shown to influence the ratio of $\mathrm{N}_{2} \mathrm{O}$ to $\mathrm{N}_{2}$ and also the denitrifier community structure (Miller et al. 2008). The addition of manure was also shown to enhance the potential activity of ammonium oxidizing bacteria, (Enwall et al. 2007), consequently affecting $\mathrm{N}_{2} \mathrm{O}$ and NO emissions.

In order to explain the reduction of $\mathrm{NO}$ and $\mathrm{N}_{2} \mathrm{O}$ emissions by the residual effect of the manure application more research is required. Investigating changes in the nitrifying and denitrifying community structure with manure application in low C soils may provide the answer to our observed differences.

Arid and semiarid lands comprise more than onethird of the earth's surface. Climate models suggest that arid areas are increasing due to global change (IPCC 2007). Their characteristic climates drive the soil to extreme conditions very rapidly. The patterns of gas emissions are complex and too few data are currently available to be included into models and scenario studies. Comparing this study with the results reported by Dick et al. (2008) and by Sanchez-Martin et al. (2008) demonstrates that residual organic $\mathrm{C}$ in the soil could be an important tool in anid-semiarid soils for mitigating $\mathrm{N}_{2} \mathrm{O}$ and $\mathrm{NO}$ emissions and at the same time increasing the general fertility of the soil.

We therefore recommend the use of organic manure in these regions as a beneficial tool both environmentally and economically, since it is more sustainable than the application of mineral fertilizers. 
Acknowledgements The authors are gratefil to the Spanish Commission of Science and Technology (Project AGL200306864) for financing part of this study, which was carried out at $\mathrm{CEH}$, Edinburgh and wish to thank the farmers for authorising the collection of soil samples.

\section{References}

Bastida F, Perez-de-Mora A, Babic K et al (2009) Role of amendments on $\mathrm{N}$ cycling in Mediterranean abandoned semiarid soils. Appl Soil Ecol 41:195-205. doi: 10.1016/j. apsoil.2008.10.009

Beauchamp EG, Trevors JT, Paul JW (1989) Carbon sources for bacterial denitrification. Adv Soil Sci 10:113-142

Birch HF (1985) The effect of soil drying on humus decomposition and nitrogen availability. Plant Soil 10;9-31, doi: $10.1007 /$ BF01343734

Breuer L, Papen H, Butterbach-Bahl K (2000) $\mathrm{N}_{2} \mathrm{O}$ emission from tropical forest soils of Australia. J Geophys Res 105:26353-26367, doj:10.1029/2000JD900424

Cabrera ML (1993) Modelling the flush of nitrogen mineralization caused by drying and rewetting soils. Soil Sci Soc Am J 57:63-66

Cardenas L, Rondón A, Johansson C et al (1993) Effect of soil moisture, temperature and inorganic nitrogen on nitric oxide emissions from acidic tropical savannah soils. $\mathrm{J}$ Geophys Res 98:14786-14790. doi: 10.1029/93JD01020

Chantigny H, Angers DA, Rochette P (2002) Fate of carbon and nitrogen from animal manure and crop residues in wet and cold soils. Soil Biol Biochem 34:509-517. doi: $10.1016 / \mathrm{S} 0038-0717(01) 00209-7$

Christensen and Tiedje (1990) Brief and vigorous $\mathrm{N}_{2} \mathrm{O}$ production by soil at spring thaw, J Soil Sci 41:1-4. doi: $10.1111 / \mathrm{j} .1365-2389.1990 . \mathrm{tb} 00039 . \mathrm{x}$

Conant RT, Klopatek JM, Klopatek CC (2001) Environmental factors controlling soil respiration in three semiarid ecosystems. Soil Sci Soc An1 J 64:383-390

Conrad R (2002) Microbiological and biochemical background of production and consumption of $\mathrm{NO}$ and $\mathrm{N}_{2} \mathrm{O}$ in soil. In: Gasche R, Papen H, Rennenberg H (eds) Trace Gas Exchange in Forest Ecosystems. Kluwer Academic, Dordrecht, Boston, London, pp 3-33

Davidson EA (1993) Soil water content and the ratio of nitrous oxide to nitric oxide emitted from soil. In: Oremland RS (ed) Biogeochemistry of Global change: Radiactively Active Gases. Chapman and Hall, New York, pp 369-386

Deng SP, Tabatabai MA (1997) Effect of tillage and residue management on enzyme activities in soils: III. Phosphatases and arylsulfatase. Biol Fertil Soils 24:141-146. doi: $10.1007 / \mathrm{s} 003740050222$

Dick J, Skiba U, Murro RC et al (2008) The contribution of agricutural practices to greenhouse gas emissions in semiarid Mali. Soil Use Manage 24:292-301 d doi:10.1111/j. 14752743.2008.00163.x

Dick J, Skiba U, Wilson J (2001) The effect of rainfall on NO and $\mathrm{N}_{2} \mathrm{O}$ emissions from Uganda agroforest soils. PhytonAnn Rei Bot 41:73-80
Doran JW, Mielke LN, Stamatiadis S (1988) Microbial activity and $\mathrm{N}$ cycling as regulated by soil water-filled pore space. Proceedings of the 11 th ISTRO Conference, Edinburgh, UK: 49-54. Conference Organizing Committee, Edinbugh, UK.

Enwall K, Nyberg K, Bertilsson S et al (2007) Long-term impact of fertilization on activity and composition of bacterial communities and metabolic guilds in agricultural soil. Soil Biol Biochem 39:106-115. doi:10.1016/j.soilbio.2006.06.015

FAO (2001) Global Estimates of Gaseous Emissions of $\mathrm{NH}_{3}$, $\mathrm{NO}$ and $\mathrm{N}_{2} \mathrm{O}$ from agricultural land. Rome, Italy

Haney RL, Franzluebbers AJ, Potter EB et al (2004) Soil carbon and nitrogen mineralization: influence of drying temperature. Soil Sci Soc Am J 68:489-492

Harwood JE, Huysen DJ (1970) Automated analysis of ammonia in water. Water Res 4:695-704, doi:10.1016/ 0043-1354(70)90031-X

Henriksen A, Selmer-Olsen AR (1970) Automatic methods for determining nitrite in water and soil extracts. Analyst (Lond) 95:514-518. doi:10.1039/an9709500514

IPCC (2007) Climate Change. In: Synthesis report of the fouth assessment report of IPCC. Chapter 3 pp: 49

Jones SK, Rees RM, Skiba UM et al (2005) Greenhouse gas emissions from a managed grassland. Global Planet Change 47:201-211, doi:10.1016/j.gloplacha.2004.10.011

Jørgensen RN, Jørgensen BJ, Nielsen NE (1998) $\mathrm{N}_{2} \mathrm{O}$ emission immediately after rainfall in a dry stubble field. Soil Biol Biochem 30:545-546. doi:10.1016/\$0038-0717(97)001442

Manugistics (2000) Statgraphic Plus Version 5.1 Manugistics Rockville, USA

Meijide A, Díez JA, Sánchez-Martín L et al (2007) Nitogen oxide emissions from an irrigated maize crop amended with treated pig slurries and composts in a Mediterranean climate. Agric Ecosyst Environ 121:383-394. doi:10.1016/j. agee.2006.11.020

Miller MN, Zebarth BJ, Dandie CE et al (2008) Crop residue influence on Denitrification, $\mathrm{N} 2 \mathrm{O}$ emissions and denitrifjer community abundance in soil. Soil Biol Biochem 40:2553-2562. doi:10.1016/j.soilbio.2008.06.024

Muller C., Martin M, Stevens RJ (2002) Processes leading to $\mathrm{N}_{2} \mathrm{O}$ emissions in grassland soil during freezing and thawing. Soil Biol Biochem 34:1325-1331. doi:10.1016/ S0038-0717(02)00076-7

Orchard VA, Cook FJ (1983) Relationship between soil respiration and soil moisture. Soil Biol Biochem 15:447453. doi: 10.1016/0038-0717(83)90010-X

Peoples MB, Herridge DF, Ladha JK (1995) Biological nitrogen fixation-an efficient source of nitrogen for sustainable agricultural production. Plant Soil 174:3-28. doi: $10.1007 / \mathrm{BF} 00032239$

Rowell DL (1994) Soil science method \& application. Longman Scientific, Essex UK, p 350

Sahrawat KL, Keeny DR (1986) Nitrous oxide emission from soils. In: Advances in soil Science 4. Springer, New York Berlin Heidelberg, pp 103-148

Sanchez-Martin L, Vallejo A, Dick J et al (2008) The influence of soluble carbon and fertilizer nitrogen on nitric oxide and nitrous oxide emissions from two contrasting agricultwal soils. Soil Biol Biochem 40:142-151. doi: 10.1016/j. soilbio.2007.07.016 
Scholes MC, Martin R, Scholes RJ et al (1997) $\mathrm{NO}$ and $\mathrm{N}_{2} \mathrm{O}$ emissions from savanna soils following the first simulated rains of the season. Nutr Cycl Agroecosyst 48:115-122. doi: $10.1023 / \mathrm{A}: 1009781420199$

Vallejo A, Skiba U, García-Torres L et al (2006) Nítrogen oxides emission from soils bearing a potato crop as influenced by fertilization with treated pig slurries and composts. Soil Biol Biochem 38:2782-2793. doi:10.1016/ j.soilbio.2006.04.040

Wemer C, Kiese R, Butterbach-Bahl K (2007) Soil-atmosphere exchange of $\mathrm{N}_{2} \mathrm{O}, \mathrm{CH}_{4}$, and $\mathrm{CO}_{2}$ and controlling environmental factors for tropical rain forest sites in western Kenya. J Geophys Res 112:D03308. doi:10.1029/ 2006JD007388 